\title{
Determining lead sources in Mexico using the lead isotope ratio
}

\author{
Madhu Chaudhary-W ebb, MS, ${ }^{(1)}$ Daniel C. Paschal, Ph D, (1) Isabelle Romieu, MD, Ph D, ${ }^{(5)}$ Bill Ting, Ph D, (1) \\ Crawford Elliot, Ph D, ${ }^{(2)}$ Harry Hopkins, Ph D, ${ }^{(3)}$ Luz Helena Sanín, MD, M PH, ${ }^{(4)}$ Mahamad A. G hazi, Ph D. ${ }^{(2)}$
}

\section{Chaudhary-Webb M, Paschal D, Romieu I,Ting B, Elliot C, Hopkins H, Sanín LH, Ghazi AM. Determining lead sources in Mexico using the lead isotope ratio. Salud Publica Mex 2003;45 suppl 2:S183-S188. This paper is available too at: http://www.insp.mx/salud/index.html}

\begin{abstract}
A bstract
Objective. Lead poisoning can, in some cases, be traced to a specific route or source of exposure on the basis of the individual's blood lead isotope ratio. To assess the major source of lead exposure among women residing in Mexico City, we compared blood, ceramic, and gasoline lead isotope ratios. Material and Methods. The study population, randomly selected from participants of a large trial, (1/199612/1996) comprised of 16 women whose lead levels exceeded $10 \mu \mathrm{g} / \mathrm{dl}$ and who reported using lead-glazed ceramics. Lead isotope ratios were performed on a Perkin Elmer 5000 Inductively C oupled Plasma Mass Spectrometer (ICP-MS) interfaced with a Perkin Elmer HGA-600MS Electrothermal Vaporization System (ETV). Results. The iso tope ratios $\left({ }^{206} \mathrm{~Pb} / 204 \mathrm{~Pb},{ }^{207} \mathrm{~Pb} / 204 \mathrm{~Pb}\right.$, and $\left.{ }^{208} \mathrm{~Pb} / 204 \mathrm{~Pb}\right)$ of both the blood specimens and their corresponding ceramic specimens were highly correlated, with $r=0.9979, r^{2}=0.9958$, $r=0.9957, r^{2}=0.9915$ and $r=0.9945, r^{2}=0.9890$ values for the three isotope ratios, respectively, suggesting that the lead exposure most likely resulted from the use of these ceramic. Measurements of lead isotope ratios from leaded gasoline in use at the time of blood sampling, differed from those in blood and ceramics. Conclusions D etermining lead isotope ratios can be an efficient tool to identify a major source of lead exposure and to support the implementation of public health prevention and control measures. This paper is available too at: http://www.insp.mx/salud/index.html
\end{abstract}

Key words: lead; ceramics; inductively coupled plasma mass spectrometry; Mexico

\author{
Chaudhary-Webb M, Paschal D, Romieu I,Ting B, \\ Elliot C, Hopkins H, Sanín LH, Ghazi AM. \\ La identificación de fuentes de exposición a plomo en México \\ a través de la determinación de la razón de isótopos de plomo. \\ Salud Publica Mex 2003;45 supl 2:S183-S188. \\ Este artículo también está disponible en: \\ http://www.insp.mx/salud/index.html
}

\section{Resumen}

Objetivo. Identificar la fuente principal de exposición a plomo entre mujeres residentes en la Ciudad de México, por medio de la comparación de las razones de isóto pos de plomo en sangre, cerámica y gasolina. Material y métodos. La población de estudio fue seleccionada aleatoriamente de participantes de una muestra obtenida de enero a diciembre de 1996 y consistió en 16 mujeres con niveles de plomo mayores a $10 \mu \mathrm{g} / \mathrm{dl}$, que usaban cerámica vidriada con plomo. Las razones de isótopos de plomo se obtuvieron con un espectrómetro de masa de plasma inductivamente acoplado (IC P-MS) Perkin Elmer 5000, en interfase con un sistema de vaporización electrotérmica (ETV) Perkin Elmer HGA-600MS. Resultados. Las razones de isóto pos $\left({ }^{206} \mathrm{~Pb} /{ }^{204} \mathrm{~Pb},{ }^{207} \mathrm{~Pb} /{ }^{204} \mathrm{~Pb}, y\right.$ y $\left.{ }^{208} \mathrm{~Pb} /{ }^{204} \mathrm{~Pb}\right)$, tanto de los especímenes de sangre, como de los de cerámica se correlacionaron fuer temente, con valores de $r^{2}$ de $0.9958,0.9915$, y 0.9890 , para las tres razones de isóto pos, respectivamente, sugiriendo que la exposición a plomo probablemente se debió al uso de la cerámica. Las mediciones de las razones de isótopos de plomo de la gasolina con plomo, que todavía se usaba al momento de la toma de muestras de sangre, fueron distintas de las encontradas en sangre y en cerámica. Conclusiones. La determinación de las razones de isótopos de plomo puede ser una herramienta eficiente para la identificación de las fuentes principales de exposición a plomo y para apoyar la implantación de medidas de salud pública para prevención y control. Este artículo también está disponible en: http://www.insp.mx/salud/index.html

Palabras clave: plomo; cerámica; espectrometría de masa de plasma acoplada inductivamente; México

\footnotetext{
(1) Centers for D isease Control and Prevention, D ivision of Environmental Health Laboratory Sciences, Atlanta (GA). 30341, United States of America (USA).

(2) Department of G eology, G eorgia State University, University Plaza, A tlanta (GA). 30309, USA.

(3) D epartment of Chemistry, G eorgia State University, University Plaza, A tlanta (GA). 30309, USA.

(4) Instituto N acional de Salud Pública, Cuernavaca, Morelos, and Universidad Autónoma de Chihuahua, Chihuahua, México.

(5) Pan American Health O rganization, México, DF, México.
}

Received on: February 6,2001 • Accepted on: June 6, 2002

Address reprint requests to: $\mathrm{D}$ ra. Isabelle Romieu. Instituto $\mathrm{N}$ acional de Salud Pública. Avenida Universidad 655 ,

Colonia Santa María A huacatitlán; 62508 Cuernavaca, Morelos, México. correo electrónico: iromieu@ correo.insp.mx 
E nvironmental lead exposure in Mexico City results from two main sources -leaded gasoline and traditional lead-glazed ceramics. ${ }^{1}$ The use of lead as an additive in gasoline has decreased since 1986, and unleaded gasoline was introduced in Mexico in $1991 .{ }^{1}$ A survey conducted to determine blood lead levels (BLLs) among the population of Mexico City showed that umbilical cord BLLs decreased from $13.5 \mu / \mathrm{dl}$ in 1980 to $6.9 \mu \mathrm{g} / \mathrm{dl}$ in $1996 .{ }^{2,3}$ However, BLLs in 33\% of women at delivery exceed $10 \mu \mathrm{g} / \mathrm{dl}^{4}{ }^{4}$ Therefore, determining the major source of lead exposure in this population is important from a public health standpoint, because of the impact of elevated BLLs on neurobehavioral development in both fetuses and children.,

Lead poisoning can in some cases be traced to a specific route or source of exposure by measuring an individual's blood lead isotope ratio. Elemental lead comprises four naturally occurring stable isotopes: ${ }^{204} \mathrm{~Pb},{ }^{206} \mathrm{~Pb},{ }^{207} \mathrm{~Pb}$, and ${ }^{208} \mathrm{~Pb}$. Except for ${ }^{204} \mathrm{~Pb}$, these isotopes are products of radioactive decay of either uranium or thorium..$^{7-9}$ Lead isotope ratio measurement -correlating body lead to possible external sources of lead exposure- is sometimes referred to as "lead fingerprinting." The isotopic content of lead introduced into a human body remains constant over time and changes only if another source of lead with differing lead isotopic content is introduced. In such a case, the body's new lead isotopic content will be a combination or mixture of the two lead sources. Since the body treats lead as one unit and does not metabolically alter it, all measurements of lead isotope ratio from a blood specimen can potentially be correlated to an outside source, if the number of lead sources are limited and little lead mixing has occurred. . $^{8,9}$

The goal of this study was to determine the major source of lead exposure among women residing in Mexico City, whose BLL's exceeded $10 \mu \mathrm{g} / \mathrm{dl}$, by comparing blood, ceramic, and gasoline lead isotope ratios. The investigation began in 1996 and was completed in 1998.

\section{Material and Methods}

Participating women were part of a double-blinded randomized trial to evaluate the impact of calcium supplementation in lactating women on their venous BLLs. The expected outcome of calcium supplementation was a decreased remobilization of lead stored in bone. This decrease would minimize lead exposure to the fetus. From January 1994 through June 1995, potential study participants were identified from maternity wards in three hospitals in Mexico City and interviewed. Methods have been described elsewhere. ${ }^{4}$ The study population initially participating in the trial comprised 529 women (270 placebo, 259 intervention). Twenty women were randomly selected from lactating women and in puerperium, who had been assigned to receive placebo and who had reported using lead-glazed ceramics. Blood samples were collected for analysis, and each woman provided one intact earthenware ceramic utensil that she routinely used for cooking and serving food. Additionally, we obtained samples of leaded gasoline and determined the isotope ratio.

The research protocol was approved by the $\mathrm{Hu}-$ man Subjects Committee of the National Institute of Public Health of Mexico. All participants received a detailed explanation of the study and procedures used, as well as counseling on reduction of lead exposure.

We measured the total lead content of the blood specimens on a Perkin Elmer Model 5100 Zeeman Graphite Furnace Atomic Absorption Spectrometer (ZGFAA). The analytical method employed was a wellestablished method used in many clinical labs in the United States. ${ }^{10,11}$

We determined the total lead content of the ceramics by measuring the leachates from each ceramic using a $4 \%$ nitric acid solution as the leaching solution on an Instruments SA JY70+ Inductively Coupled Plasma Optical Emission Spectrometer (ICP-OES) ${ }^{9,10}$ Samples of the nitric acid solution were collected at 1 hour, 6 hours, and at 24 hours, from each container. ${ }^{10}$

The isotope ratio measurements were performed on a Perkin Elmer ELAN 5000 Inductively Coupled Plasma Mass Spectrometer (ICP-MS) interfaced with a Perkin Elmer HGA-600MS Electrothermal Vaporization System (ETV) $)^{10,12-14}$ described in a previous publication. We assessed the accuracy of isotope ratio measurements comparing the levels which were determined to the target value of know composition. The percent age error varied between $-0.2 \%$ to $3.1 \% .{ }^{10}$

For statistical analysis, we compared the isotope ratios 206pb/204pb, 207pb/204pb and 208pb/204pb from each blood analysis, with isotope ratios from the earthenware ceramic specimen obtained from the same household, to determine whether lead exposure was likely to have been caused from using the earthenware. Similarly, the blood isotope ratios were compared with the gasoline isotope ratios. ${ }^{10}$

Lead ratios were measured for blood specimens with lead values greater than or equal to $10 \mu \mathrm{g} / \mathrm{dl}(\mathrm{N}=16)$. Lead isotope ratios for the blood, aqueous pottery leachates, and gasoline extracts, were tabulated and compared with each other to determine possible statistically significant correlations. We obtained the association between each blood specimen and its corresponding ceramic by calculating slopes for each blood/ceramic pair. 
The group correlation of all the blood samples to the ceramics within each isotope ratio was also calculated..$^{10}$ In addition we calculated the Mahalanobis distance between lead isotope ratios present in blood, and gasoline and blood and ceramic pots. ${ }^{15}$

\section{Results}

Table I presents the total BLLs of the 16 women whose levels exceeded $10 \mu \mathrm{g} / \mathrm{dl}$ and the lead isotope ratios of the blood samples and their corresponding ceramics for each woman. The blood and ceramic isotope ratios from each woman/ceramic pair match with each other. The highest errors were observed in the ${ }^{208} \mathrm{~Pb} /{ }^{204} \mathrm{~Pb}$ ratio measurements because of the difference in the relative abundance of the two isotopes. The ${ }^{208} \mathrm{~Pb}$ isotope signal is 37 times more intense than the ${ }^{204} \mathrm{~Pb}$ isotope, leading to higher measurements and precision errors.

Table II reports the isotope ratio association between each blood specimen to its corresponding ceramic specimen from that household, as determined by the calculated slopes of each pair. Additionally, a total group correlation was calculated for all the blood/

Table I

BLOOD DATA MATCHED TO THE POTTERY SPECIMEN FROM THE SAME HOUSEHOLD AND ITS CORRESPONDING TOTAL lead value, Mexico City, 1996

\begin{tabular}{|c|c|c|c|c|c|}
\hline \multirow[b]{3}{*}{ Blood ID } & \multirow{3}{*}{$\begin{array}{c}(\mathrm{ug} / \mathrm{dl}) \\
\text { Total Pb }\end{array}$} & \multicolumn{4}{|c|}{ Isotope ratios } \\
\hline & & \multicolumn{2}{|c|}{${ }^{206} \mathrm{~Pb} / 204 \mathrm{~Pb}$} & ${ }^{207} \mathrm{~Pb} / 204 \mathrm{~Pb}$ & ${ }^{208} \mathrm{~Pb} /{ }^{204} \mathrm{~Pb}$ \\
\hline & & Blood & Pot & Blood Pot & Blood Pot \\
\hline 01 & 15.4 & 19.45 & 19.54 & 16.18416 .20 & 40.271 \\
\hline \multicolumn{6}{|l|}{40.42} \\
\hline 02 & 14.4 & 19.42 & 19.31 & 16.28116 .01 & 41.2239 .41 \\
\hline 03 & 22.4 & 19.00 & 19.75 & 16.10516 .05 & 38.7639 .75 \\
\hline 04 & 15.8 & 19.05 & 19.28 & 16.10816 .62 & 39.6341 .12 \\
\hline 05 & 12.2 & 18.90 & 19.20 & 16.01216 .25 & 39.0840 .19 \\
\hline 06 & 12.4 & 19.46 & 19.10 & 16.13016 .47 & 39.8840 .54 \\
\hline 08 & 13.4 & 19.20 & 19.31 & 16.18015 .63 & 38.7140 .33 \\
\hline 09 & 12.4 & 19.32 & 20.12 & 16.04116 .58 & 39.3841 .66 \\
\hline 10 & 16.2 & 19.11 & 18.94 & 16.13115 .98 & 39.2539 .89 \\
\hline 11 & 27.4 & 18.69 & 18.78 & 15.62016 .54 & 39.0239 .57 \\
\hline 12 & 32.0 & 19.15 & 19.39 & 16.00116 .14 & 40.289 \\
\hline \multicolumn{6}{|l|}{41.39} \\
\hline 13 & 11.4 & 19.43 & 19.54 & 16.13016 .18 & 39.6441 .11 \\
\hline 14 & 72.8 & 18.47 & 18.67 & 15.46216 .00 & 36.945 \\
\hline \multicolumn{6}{|l|}{39.69} \\
\hline 15 & 30.0 & 19.08 & 19.24 & 15.82515 .75 & 38.8838 .76 \\
\hline 17 & 15.4 & 19.06 & 19.50 & 15.93616 .40 & 39.6540 .33 \\
\hline 20 & 11.8 & 19.09 & 18.87 & 16.06016 .00 & 38.7138 .77 \\
\hline
\end{tabular}

Updated from reference 9 ceramic pairs for each isotope ratio. The slopes were very close to 1 and correlation coefficients $\left(r^{2}=0.99\right.$ or better) strongly suggesting that use of ceramics was a significant contributor to the women's blood lead level, given the accuracy of the method (see methods).

We compared the average isotope ratios of the ceramics with the average isotope ratios obtained for the blood specimens. The lead isotope ratios of both the blood and the ceramic resemble the lead isotope ratios found in the local mines of Mexico or California, making them the most likely source of lead in these specimens. ${ }^{5,12,13}$ Additionally, the average isotope ratios for the blood samples and their corresponding ceramics from the same household showed a high degree of correlation, suggesting that lead exposure for these women resulted from their use of these ceramics.

The blood isotope ratios were tightly clustered. By comparing each blood lead isotope ratio with the corresponding 1 hour leachate lead isotope ratio of the pottery obtained from the same household, we observed that the isotopic content of the blood specimens and the ceramic leachates were virtually identical. This high correlation for all three isotope ratios indicates that the pots are the most likely source of lead in blood (Figure 1); however, exposure to an additional source

Table II ISOTOPE RATIO COMPARISON OF EACH BLOOD SPECIMEN
TO ITS CORRESPONDING 1-HOUR POTTERY LEACHATE.
MEXICO CITY, 1996

\begin{tabular}{lllll} 
Blood ID & Pot ID & \multicolumn{4}{c}{ Slopes } \\
& & & \\
& & & \\
01 & $3-1914$ & 1.005 & 1.001 & 1.004 \\
\hline 02 & $3-1812$ & 0.994 & 0.983 & 0.956 \\
\hline 03 & $3-1926$ & 1.040 & 0.997 & 1.026 \\
\hline 04 & $3-1762$ & 1.012 & 1.032 & 1.038 \\
\hline 05 & $3-3029$ & 1.016 & 1.015 & 1.028 \\
\hline 06 & $3-2502$ & 0.982 & 1.021 & 1.016 \\
\hline 08 & $3-1872$ & 1.006 & 0.966 & 1.042 \\
\hline 09 & $3-2347$ & 1.042 & 1.034 & 1.058 \\
\hline 10 & $3-2349$ & 0.991 & 0.991 & 1.016 \\
\hline 11 & $3-2442$ & 1.005 & 1.059 & 1.014 \\
\hline 12 & $3-3232$ & 1.012 & 1.009 & 1.027 \\
\hline 13 & $3-3020$ & 1.006 & 1.003 & 1.037 \\
\hline 14 & $3-3143$ & 1.011 & 1.035 & 1.074 \\
\hline 15 & $3-1841$ & 1.008 & 0.995 & 0.997 \\
\hline 17 & $3-2225$ & 1.023 & 1.029 & 1.017 \\
\hline 20 & $3-1827$ & 0.989 & 0.996 & 1.002
\end{tabular}

Total correlation of all points for ${ }^{206} \mathrm{~Pb} /{ }^{204} \mathrm{~Pb}$ slope $=1.008, r=0.9979, r^{2}=0.9958$ Total correlation of all points for ${ }^{207} \mathrm{~Pb} / 204 \mathrm{~Pb}$ slope $=1.007, r=0.9957, r^{2}=0.9915$ Total correlation of all points for ${ }^{208} \mathrm{~Pb} /{ }^{204} \mathrm{~Pb}$ slope $=1.015, r=0.9945, r^{2}=0.9890$ 

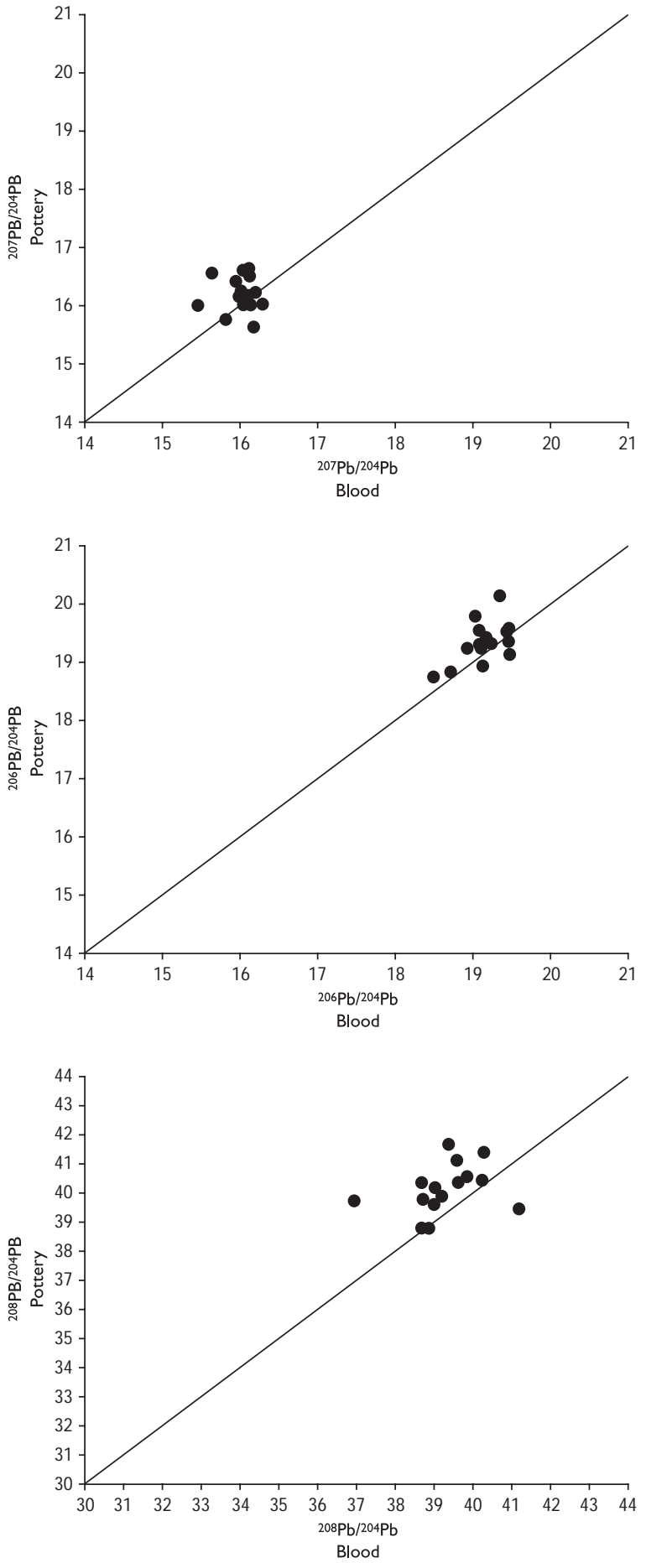

Figure 1. Isotope RATIOS OF BLOOD COMPARED WITH CORRESPONDING POTTERY FOR ${ }^{206} \mathrm{~PB} /{ }^{204} \mathrm{~PB},{ }^{207} \mathrm{~PB} /{ }^{204} \mathrm{~PB}$.

THE STRAIGHT LINE IN EACH GRAPH REPRESENTS A LINE OF SLOPE=1.THE PROXIMITY OF THE POINTS TO THE LINE ON EACH GRAPH INDICATES THAT THE BLOOD AND POTTERY HAVE SIMILAR ISOTOPE RATIOS in conjunction with the pottery cannot be totally discounted.

We subsequently measured lead isotope ratios from leaded gasoline in typical use at the time of sampling. The isotope ratios measured for gasoline differed from those in blood or ceramics. Figure 2 shows the clustering of the blood and ceramic isotope ratios in comparison to the distinctly different gasoline lead isotope ratios.

In addition, we calculated the Mahalanobis distance between blood and gasoline, including the 3 lead isotope ratios, which gave a result of $4.6(p<0.001)$ suggesting that isotopes ratios were significantly different. The Mahalanobis distance between the lead isotope ratios of blood and ceramic pots was 2.3, suggesting that lead ceramic was the main source of blood lead.

\section{Discussion}

The lead isotope ratios in blood and in ceramic were highly correlated, strongly suggesting that use of leadglazed ceramic was the major source of lead exposure in our population. In contrast, the gasoline lead isotope differed, indicating that gasoline was not of major concern for our population.

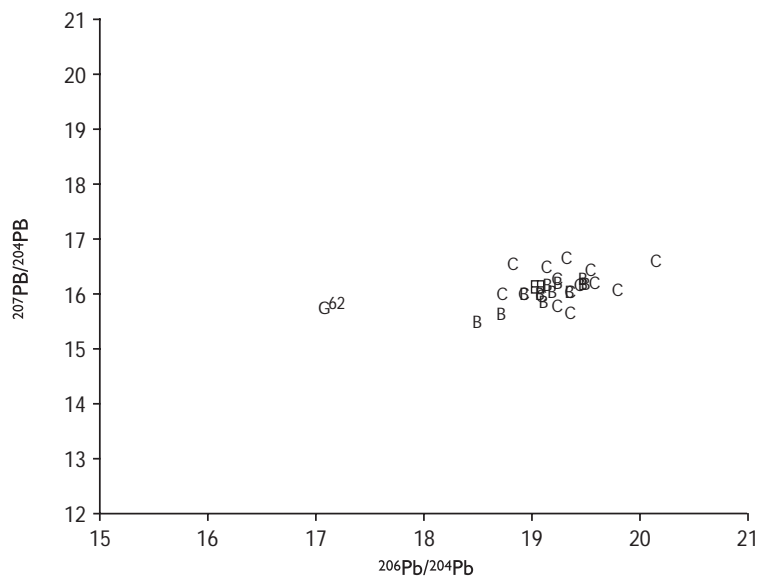

Figure 2. Comparison of Isotope Ratios (207PbB $204 \mathrm{~PB}$ VERSUS ${ }^{206} \mathrm{~PB} /{ }^{204} \mathrm{~PB}$ ) FOR ALL BLOOD, CERAMIC, AND GASOLINE. All "B" SYMBOLS=BLOOD POINTS, "C"=CERAMIC POINTS, AND "G"=GASOLINE POINTS.THE TWO GASOLINE POINTS ARE SIGNIFICANTLY SEPARATED FROM THE CLUSTER OF BLOOD AND CERAMIC POINTS.THE CLUSTERING INDICATES THAT THE BLOOD AND CERAMIC ISOTOPE RATIOS ARE SIMILAR.THIS INDICATES THAT GASOLINE IS NOT LIKELY TO BE THE SOURCE OF LEAD EXPOSURE, BUT THAT CERAMICS ARE HIGHLY LIKELY TO BE THE LEAD SOURCE 
These results agree with reports from Mexico City that observed a strong correlation of elevated blood lead with use of ceramic cookware ${ }^{14,16,17}$ and elevated BLLs among ceramic workers in Mexico. ${ }^{18}$

Determining lead isotope ratios has been used to identify sources of exposure. Delves reported high correlations between paint and water lead ratios and blood lead ratios, $5,12,19,20$ Where the source of lead exposure is not clearly established, determining lead isotope ratios in blood and corresponding environmental samples may help determine the major source of exposure and allow for primary prevention, permitting the persons at risk to eliminate or minimize their exposure. There are, however, limitations to this technique. For isotope measurement ("lead fingerprinting") to be useful, potential sources of lead exposure must be limited in number and scope, and the lead sources must be isotopically distinct. If two or more sources of lead exist internally (within the body) or externally (in the environment), mixed isotope ratios result, reflecting a combined isotope ratio of all the sources of exposure. Such mixed isotope ratios generally provide no useful information in identifying lead sources because they then represent the average lead isotope ratio, and separation into the original isotope ratios is difficult ${ }^{7,19,21,22}$ Another important factor is the accumulated lead in bone. Long after lead exposure has ceased and BLLs have dropped, a new stress on the body (such as a bone break or pregnancy) could shift the equilibrium and consequently release accumulated stores of lead from the bones, elevating the BLLs independent of a current external source of exposure. Lead exposure would then be difficult to attribute to any external source if demographics such as employment, housing, or the living conditions of the exposed person had changed since the initial exposure. ${ }^{6,7}$ Although women in our sample were lactating, which increases the lead mobilization from their bones, their living conditions had not changed over time; therefore, the source of their lead exposure would not have changed dramatically over time. Any blood lead isotope ratios measured for this population sample would probably represent current exposure. The lead isotope ratios measured for the women in this study, compared with the lead isotope ratios measured for the ceramics, strongly suggest the ceramics are the major contributor of lead exposure in these women. The gasoline lead isotope ratios are sufficiently distinct from the blood lead isotope ratios to eliminate them as a possible lead exposure source in these women. ${ }^{7,8}$

The number of women in our study was small, but given the large difference in lead isotope ratios between lead-glazed ceramics and gasoline, the techniques we used were likely to discriminate between the different lead sources. The large difference in lead isotope ratios between gasoline and lead glaze suggests that the lead used in these two media originated from different sources. In Mexico, the lead tetraethyl added to gasoline by the government-owned petroleum company (Pemex) comes from providers outside of Mexico. In contrast, the lead used to prepare ceramic glazes comes from ores different to those ores used in lead tetraethyl and which is likely to have been extracted from Mexican mines.

These results are of major public health relevance because of the widespread use of lead- glazed ceramic in Mexico -approximately $40 \%{ }^{22,23}$ Alternative technology is available based on a borate glaze that is inert and provides ceramics with similar aesthetic to the traditional. Public programs are needed to promote and implement alternative technology to decrease the lead burden of the Mexican population.

\section{Referencias}

1. Romieu I, Palazuelos E, Hernández-Avila M, Ríos C, Muñoz I, Jiménez $C$ et al. Sources of lead exposure in Mexico City. Environ Health Perspect 1994;102:384-389.

2. Hernández-Avila M. El plomo: un problema de salud pública en México. En: Hernández-Avila M, Palazuelos-Rendón E, ed. Intoxicación por plomo en México: prevención y control. Cuernavaca, Morelos, México: Instituto N acional de Salud Pública, 1995; Perspectiva en Salud Pública 21:13-24.

3. Sanín LH, G onzález-C ossío T, Romieu I, Peterson KE, Ruiz S, Palazuelos E. Effects of maternal lead burden on infant weight and weight gain at one month of age among breastfed infants. Pediatrics 2001; 107:1016-1022.

4. González-C ossío T, Peterson K, Sanín LH, Fisbein E, Palazuelos E, Aro $A$ et al. Decrease in birth weight in relation to maternal bone-lead burden. Pediatrics 1997;100:1-7.

5. Palazuelos-Rendón E. Effects of lead on children's health. En: Howson CP, Hernández-Avila M, Rall DP, Ed. Lead in the Americas:A call for action. Cuernavaca, Morelos, México: $\mathrm{N}$ ational Institute of Public $\mathrm{Health}$, 1995: 59-67.

6. Inskip MJ, Franklin CA, Subramanian KS, Blenkinsop J,W andelmaier F. Sampling of cortical and trabecular bone for lead analysis: Method development in a study of lead mobilization during pregnancy. N eurotoxicology 1992; 13:825-834.

7. Russell RD, Farquhar RM. Lead isotopes in geology. N ueva York (N Y), Interscience Publishers, 1960.

8. Rabinowitz MB. Imputing lead sources from blood lead isotope ratios. En: Beard ME, Iske SDA, Ed. Lead in paint, soil, and dust: Health risks, exposure studies, control measures, measurement methods, and quality assurance,ASTM STP 1226. Filadelfia (PA):American Society for Testing and Materials, 1995: 63-75.

9. Lieser KH, Fey W. Isotopic fingerprint method:Assessment of the origin of rare-earth compounds from the isotope ratios of lead impurities. Fresenius J Anal Chem 1995; 351:129-133.

10. C haudhary-W ebb M, Paschal DC, Elliot W C, Hopkins HP, G hazi AM, Ting BC et al. ICP-MS determination of lead isotope ratios in whole blood, pottery, and leaded gasoline: Lead sources in Mexico City. Atomic Spectroscopy 1998; 19:156-163. 
11. Fassel VA . Q uantitative elemental analyses by plasma emission spectroscopy. Science 1978;202:183-191.

12. Faure G. Principles of isotope geology. N ueva York (N Y): 1986:

227-247.

13. Ghazi AM. Lead in archaeological samples: An isotopic study by ICP-MC. Appl Geochem 1994; 9:627-636.

14. Hernández-Avila M, Romieu I, Ríos C, Rivero A, Palazuelos E. Leadglazed ceramic as major determinants of blood lead levels in Mexican women. Environ Health Perspect 1991; 94:117-120.

15. Morrison DF. Multivariate statistical methods. 3a. Ed., Pennsylvania: Ed. Mc Graw-Hill, 1990:177-178.

16. Romieu I, Carreón T, López L, Palazuelos E, Ríos C, ManuelY et al. Environmental urban exposure and blood lead levels in children of Mexico City. Environ Health Perspect 1995; 103:1036-1040.

17. Rothenberg SJ, Schnaas L, Perroni E, Hernández RM, Karchmer S. Secular trend in blood lead levels in a cohort of Mexico City children. Arch Environ Health 1998; 53:231-235.

18. Fernández GO, Martínez RR, Fortoul TI, Palazuelos E. High blood lead levels in ceramic folk art workers in Michoacan, Mexico. Arch Environ Health 1997; 52:51-55.
19. Ketterer ME.Assessment of overall accuracy of lead isotope ratios determined by inductively coupled plasma mass spectrometry using batch quality control and the Youden two-sample method. J Anal At Spectrom 1992; 7:1128-1129.

20. Delves HT, C ampbell MJ. Measurements of total lead concentrations and of lead isotope ratios in whole blood by use of inductively coupled plasma source mass spectrometry. J Anal At Spectrom1998;3:343-348. 21.Yaffe Y, Flessel CP,W esolowski J], D el Rosario A, Guirguis GN , Matías $V$ et al. Identification of lead sources in California children using the stable isotope ratio technique. Arch Environ Health 1983; 38:237-245. 22. Hernández-Avila M, Sanín LH, Romieu I, Palazuelos E,Tapia-C onyer $R, 0$ láiz $G$ et al. Higher milk intake during pregnancy is associated with lower maternal and umbilical cord lead levels in postpartum women. Environ Res 1997; 74:116-121.

23. Lacasaña-N avarro M, Romieu I, Sanín-A guirre LH, Palazuelos-Rendón E, Hernández-A vila M. Consumo de calcio y plomo en mujeres en edad reproductiva. Rev Invest Clin 1996;48:425-430. 